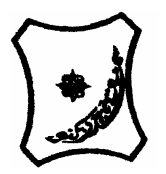

Bayero Journal of Pure and Applied Sciences, 7(2): 44 - 51

Received: December 2013

Accepted: November 2014

ISSN $2006-6996$

\title{
IMPACT OF GENETIC TRANSFORMATION ON MORPHOLOGICAL EXPRESSION OF TRANSGENIC COWPEA
}

\author{
* $^{\mathbf{1}}$ Mohammed, B.S., Ishiyaku, M.F., Abdullahi, U.S. and Katung, M.D. \\ ${ }^{1}$ Department of Plant Science, Ahmadu Bello University, Zaria, Kaduna State, Nigeria \\ Corresponding author: binsaba@yahoo.co.uk
}

\begin{abstract}
Two genetically engineered cowpea lines(TCL-709 and TCL-711) were evaluated under field conditions along with the original parental genotype (IT86D-1010) at confined field trial site Samaru Nigeria for expression of morpholgical traits. The present study was designed and conducted in order to understand whether genetic transformation of cowpea with Cry1Ab gene had led to unwanted changes on the morphological features of transgenic cowpea lines, by making comparative assessment between the transgenic lines and untransformed original parental genotype. The result showed that comparison made between transgenic cowpea line TCL-709 and original parental type showed non-significant differences in all the parameters compared. Similarly, comparison made between cowpea transgenic line TCL-711 and IT86D-1010 had significant differences for days to first flowering, days to first pod maturity and plant height while vegetative traits such as number of primary branches, yield attributes like total number of pods per plant at maturity were not significantly different from the original parent. The most important character in a crop-improvement programme is yield, the result indicated that the genotypes (TCL-709, TCL-711 and IT86D-1010) had non-significant differences among themselves regarding total number of pods per plant. It is therefore concluded that the introduction of Cry1Ab gene has not led to harmful changes on the gross morphological characteristics of cowpea plants, besides conferring insect resistance to Maruca pest.
\end{abstract}

Keywords; Cry1Ab-Transgene, Genetic Transformation, Transgenic-Cowpea

\section{INTRODUCTION}

Cowpea is the most important legume crop and the source of food for over 200 million people in sub Saharan Africa (AATF, 2010; NGICA, 2002). More than $70 \%$ of cowpea is produced and consumed in Africa (Kushwaha et al., 2004). The global production of cowpea is over 6Mt (Abate et al., 2012) and cowpea productivity is severely affected by several abiotic and biotic stresses, including damage caused by insect pests (Darshana et al., 2007). Maruca Pod Borer (MPB) is a chronic pest in all cowpea-growing environments in Africa (Sharma et al., 1999). They cause more yield loss than any other group of cowpea field insect pests (Fatokun, 2009), Use of chemicals not only increase the cowpea production cost but also causes health hazards to cowpea farmers, non target organisms and deteriorates environment (Fatokun, 2009). Using conventional breeding, several hundreds of accessions of cultivated cowpea and its wild relatives have also been screened for resistance to this pest by the International Institute of Tropical Agriculture. Accessions belonging to Vigna vexillata were found to be resistant to $M$. vitrata. These accessions were found to be closest to cowpea in a phylogenetic study of diversity in the Vigna species. Efforts were made to cross cowpea with $V$. vexillata but without success. This strong cross-incompatibility makes gene exchange between the two species impossible. This led to genetic transformation of an advanced breeding line with Cry1Ab gene at the Commonwealth Scientific and Industrial Research Organization Laboratory, Canberra, Australia (Fatokun, 2009; Ishiyaku, 2010). Genetic engineering experiments are conducted with a specific objective in mind. The scientists aim to transfer foreign DNA into a host organism and effect specific changes within that organism (Holdrege, 2008). However, each genetic transformation exercise results in a different change in the genetic architecture of the cells. There are numerous ways in which the genetic transformation can affect changes in the host organism (Holdrege, 2008). The site of gene insertion and the copy number are not always the same (Khan, 2008). There may be up-regulation or down-ward regulation of some native genes due to the insertion of a foreign gene, some native genes may become silenced or silenced genes may become active due to the pleiotropic effects of foreign gene (Khan, 2008). Each transgenic plant has its unique genetic architecture and level of expression. When an organism is genetically altered, changes in its morphology, physiology, or metabolism will change the way it relates to its environment (Holdrege, 2008). It is therefore imperative that transformed cowpea plants be studied for any unintended change in plants by comparative assessment between genetically engineered lines and the untransformed parent having the same genetic make up except the engineered foreign gene.

This study was carried out to evaluate the effect of genetic transformation on the expression of morphological traits in cowpea. This Research was conducted under the confined field conditions between June, 2012 to September, 2012 at the Institute for Agricultural Research (IAR), Samaru Nigeria. Two genetically engineered cowpea line; TCL709 and TCL-711 and the untransformed parent (IT86D-1010) were used. The description of the genetic materials used is given in Table 1. 


\section{MATERIALS AND METHODS \\ Field Evlauation}

The two transgenic lines (TCL-709 and TCL-711) and IT86D-1010 were evaluated under field conditions during the 2012 cowpea growing season at the confined field trial site (CFT) Samaru. The trial was planted using randomized complete block design with three replications. The plant to plant and row to row spacing was kept at $30 \mathrm{~cm}$ by $75 \mathrm{~cm}$ respectively. The plot size was $3 \mathrm{~m} \times 5 \mathrm{~m}$ and no insecticidal spray against lepidopteran insects was applied. Data were recorded for the following parameters viz; Days to first flowering, Days to first pod maturing, Plant Height in (cm), Number of primary branches at vegetative stage, Total number of pods per Plant at maturity and Number of pods damaged by Maruca while the observations on the following qualitative characters namely; leaf shape, pod shape, node pigmentation, flower colour, stem pigmentation, peduncle pigmentation, pod pigmentation, reaction to Maruca, of the transgenic and non- transgenic cowpeas were also taken during the present study. These characters were compared between the transgenic cowpea lines and the original genotype, to see if any unintended changes had occurred in the transgenic cowpeas lines after the genetic transformation.

\section{Statistical Analysis}

The data recorded on individual plant basis were subjected to analysis of variance and least significant difference (LSD) method was used to separate the means where significant differences existed. Pairedwise comparison were made for the plants of cowpea line IT86D-1010 and the transgenic lines TCL-709 and TCL-711 for the quantitative morphological traits measured.

\section{RESULTS}

\section{Days First Flowering}

The days to first flowering are represented in Figures 1 and 2. Statistically, the TCL-709 and IT86D-1010 had no significant differences among themselves in the number of days it takes to first flowering (Table 3), while TCL-711 and IT86D-1010 had highly significant differences in days to first flowering (Table 3). It means that the $C r y 1 A b$ gene had exerted no Tra significant effect on days to first flowering of the TCL709, as expected. However, the gene exerted negative effect on the line TCL-711, delaying flowering later than the original genotype (Table 3 ).

\section{Days to First Pod Maturity}

The Days to first pod maturity are shown in Figures 3 and 4. Statistically, the TCL-709 and IT86D-1010 had no significant differences among themselves in the number of days it takes to first pod maturity (Table 3), while TCL-711 and IT86D-1010 had a highly significant difference in days to first pod maturity
(Table 3). It means that the $C r y 1 A b$ gene had exerted no significant effect on the number of days to first pod maturity of the TCL-709. However, the Cry1Ab gene exerted negative effect on TCL-711, making its pods to mature later than IT86D-1010 (Table 3).

\section{Plant Height}

The plant height of the genotypes (TCL-709, TCL-711 and IT86D-1010) under comparison are presented in Figures 5 and 6 . The results revealed that differences among the genotypes were not significant statistically for TCL-709 and IT86D-1010 (Table 3); which means that, the $C r y 1 A b$ gene had exerted no effect on plant height. Transgenic line TCL-711 and IT86D-1010 had significant difference in their heights (Table 3 ). The insertion of $C r y 1 A b$ gene had affected the height of the line TCL-711, making it generally shorter than the IT86D-1010.

\section{Number of primary Branches per Plant at vegetative stage}

A perusal of the (Table 3 ) indicates that the lines (TCL-709, TCL-711 and IT86D-1010) did not differ in respect of number of primary branches per plant. The results clearly indicated that the genetic transformation had not affected this character. The number of primary branches data is given in Figures 7 and 8.

\section{Total Number of Pods at maturity}

The results on the total numbers of pods are presented in Figures 9 and 10. The results showed that the genotypes had no significant differences among themselves in relation to the total number of pods per plant (Table 3 ). It means that the insertion of $C r y 1 A b$ gene had exerted no significant effect on the number of pods produced per plant. It was as expected because the $C r y 1 A b$ gene is not a yield contributing gene. However, theoretically the transgenic genotypes might have higher yield than the non-transgenic check due to the enhanced insect resistance capability of the transgenic plants as an indirect effect.

Comparison of some Qualitative traits of rangenic lines and the untransformed parent

The comparisons of transgenic and non- transgenic parent is presented in (Table 4). The Hastate (Narrow) leaf shape of the genotypes remained unchanged after transformation. Similarly, pod shape remained erect even after transformation. The stem, pod and peduncle, pigmentations were the same in the transgenic cowpea lines as in the original genotype. The plant reaction to Maruca was found to be susceptible in case of non-transgenic cowpea genotype. It was however, resistant in case of transgenic cowpea lines (Table 4). 
Bajopas Volume 7 Number 2 December, 2014

Table 1: The Pedigree and Description of the Parental materials used in the Experiment Genotypes Pedigree Description

TCL-709 Transformation Event derived from IT86D1010.

TCL-711

IT86D-1010
Transformation Event derived from IT86D1010.

Derived from a
cross between
TVx4659-03E
X
IT82E-60
Sourced from Common Wealth Scientific and Industrial Research Oorganization Labouratory Canberra Australia. It's a transgenic cowpea line resistant to Maruca vitrata.

Sourced from Common Wealth Scientific and Industrial Research Oorganization Labouratory Canberra Australia. It's a transgenic cowpea line resistant to Maruca vitrata.

It's an advanced breeding line, medium maturity (71days), photo-insensitive variety with semi-erect plant growth habit. It has combined resistance to cowpea yellow mosaic, blackeye cowpea mosaic and many strains of cowpea aphid borne mosaic, Cercospora, smut, rust, Septoria, scab, Ascochyta blight, bacterial blight, anthracnose, nematodes, Striga, Alectra, ahpid, thrips and bruchid (Singh et al., 2002).

Table 2: Analysis of Variance for different characters of the field Evaluation at CFT, Samaru, 2012.

\begin{tabular}{lllllll}
\hline $\begin{array}{l}\text { Source of } \\
\text { Variation }\end{array}$ & $\begin{array}{l}\text { Days to } \\
\text { First } \\
\text { Flowering }\end{array}$ & $\begin{array}{l}\text { Days to } \\
\text { First Pod } \\
\text { Maturity }\end{array}$ & $\begin{array}{l}\text { Plant } \\
\text { Height in } \\
\mathbf{( c m )}\end{array}$ & $\begin{array}{l}\text { Total Number } \\
\text { of Pods }\end{array}$ & $\begin{array}{l}\text { Number of } \\
\text { Primary } \\
\text { Branches }\end{array}$ & $\begin{array}{l}\text { Number of } \\
\text { Pods } \\
\text { Damaged }\end{array}$ \\
\hline Replication & $2.69^{\mathrm{ns}}$ & $14.59^{\mathrm{ns}}$ & $5344.04^{\mathrm{ns}}$ & $804.04^{\mathrm{ns}}$ & $3.64^{*}$ & $39.77^{\mathrm{ns}}$ \\
Genotypes & $31.06^{* *}$ & $151.28^{* *}$ & $23855.23^{* *}$ & $1737.01^{* *}$ & $0.83^{\mathrm{ns}}$ & $914.87^{* *}$ \\
Error & 3.45 & 4.80 & 1787.48 & 264.40 & 0.83 & 17.23 \\
\hline
\end{tabular}

$*$ = significant differences at $\mathrm{P}<0.05$ probability level,

$* *$ = significant differences at $\mathrm{P}<0.01$ probability level,

NS = non significant difference.

Table 3: Mean performance of the Cowpea lines evaluated under field conditions at CFT, Samaru, 2012.

\begin{tabular}{lcccccc}
\hline Genotypes & $\begin{array}{l}\text { Days to } \\
\text { First } \\
\text { Flowering }\end{array}$ & $\begin{array}{l}\text { Days to } \\
\text { First pod } \\
\text { maturity }\end{array}$ & $\begin{array}{l}\text { Plant } \\
\text { Height } \\
\text { in } \mathbf{( c m )}\end{array}$ & $\begin{array}{l}\text { Total } \\
\text { number of } \\
\text { Pods per } \\
\text { plant }\end{array}$ & $\begin{array}{l}\text { Number of } \\
\text { Primary } \\
\text { Branches } \\
\text { per plant }\end{array}$ & $\begin{array}{l}\text { Number of } \\
\text { Pods } \\
\text { Damaged } \\
\text { per plant }\end{array}$ \\
\hline IT86D-1010 & 44.75 & 64.28 & 160.28 & 34.00 & 5.13 & 11.07 \\
TCL-709 & 45.96 & 64.48 & 137.29 & 43.00 & 5.04 & 0.00 \\
TCL-711 & 47.65 & 69.25 & 82.99 & 26.00 & 5.40 & 1.95 \\
LSD & 1.22 & 1.40 & 29.19 & 9.22 & 0.60 & 2.35 \\
\hline
\end{tabular}

Table 4: Comparison of some Qualitative traits among Transgenic and the untransformed cowpea lines

\begin{tabular}{llll}
\hline Feature & TCL-709 & TCL-711 & $\begin{array}{l}\text { IT86D-1010 } \\
\text { (Non- } \boldsymbol{B t} \text { line) }\end{array}$ \\
\hline Leaf shape & Hastate (Narrow) & Hastate (Narrow) & Hastate (Narrow) \\
Pod shape & Erect & Erect & Erect \\
Stem pigmentation & Green & Green & Green \\
Peduncle pigmentation & Green & Green & Green \\
Flower color & White to light purple & White to light purple & White to light purple \\
Pod pigmentation & Green & Green & Green \\
Node pigmentation & Purple & Purple & Purple \\
Reaction to Maruca & Resistant & Resistant & Susceptible \\
\hline
\end{tabular}




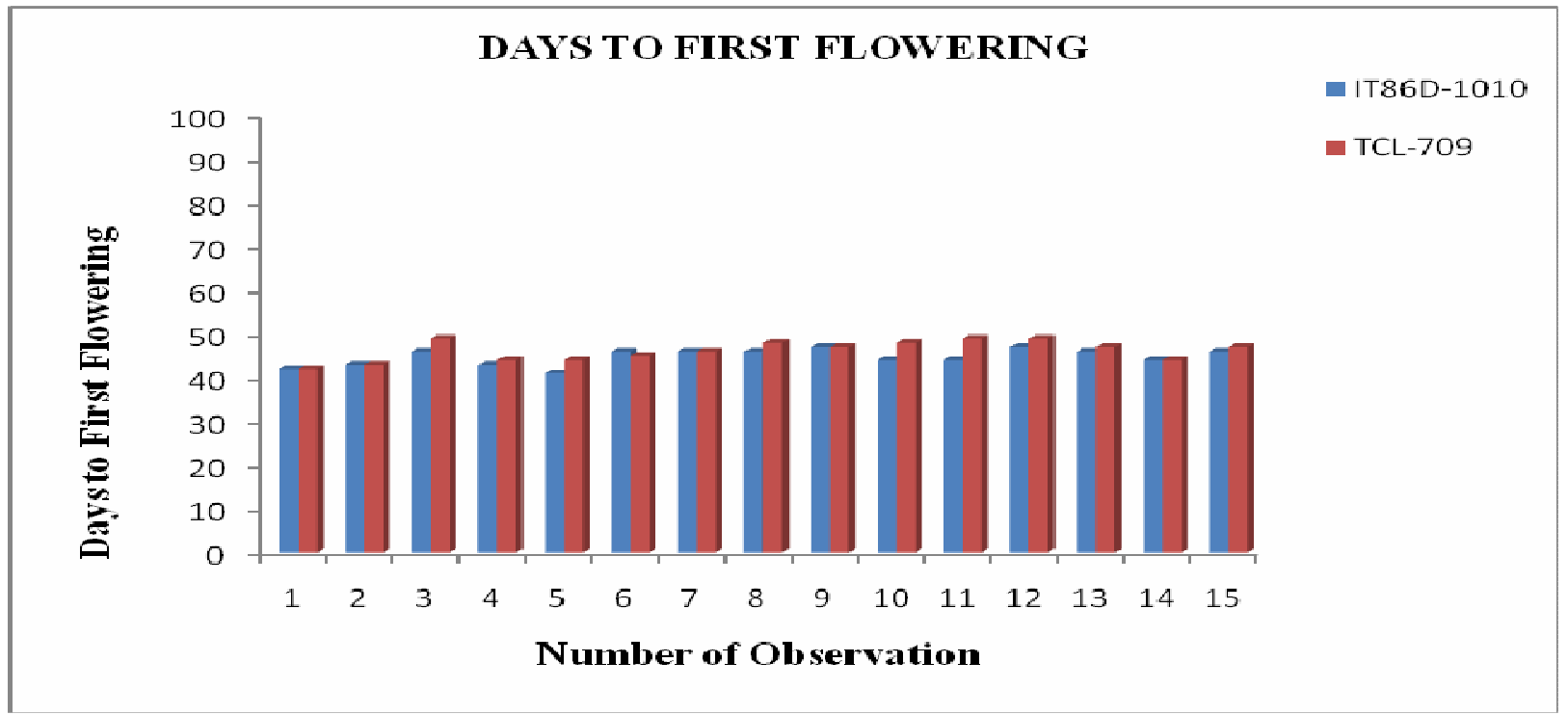

Figure 1: Days to First Flowering for IT86D-1010 and Transgenic line TCL-709

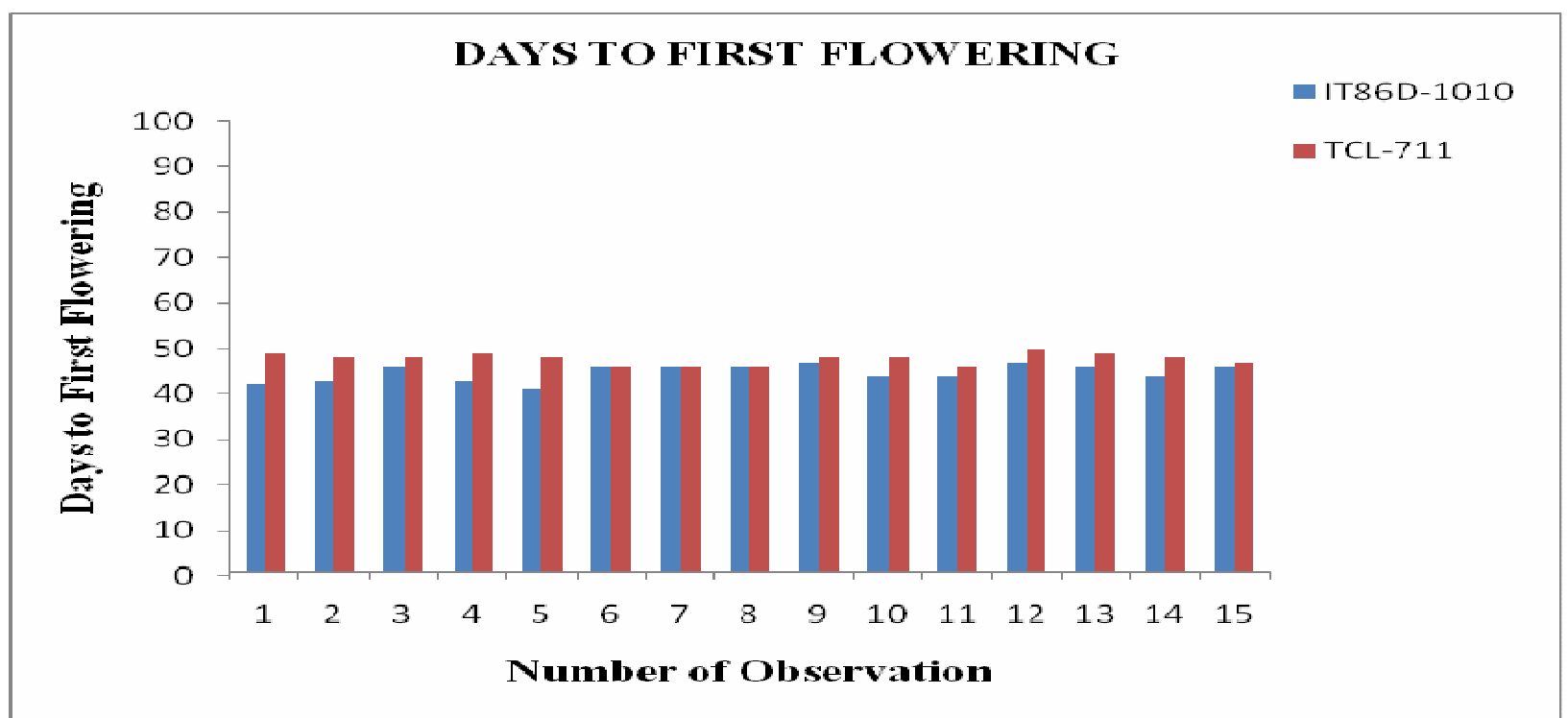

Figure 2: Days to First Flowering for IT86D-1010 and Transgenic line TCL-711

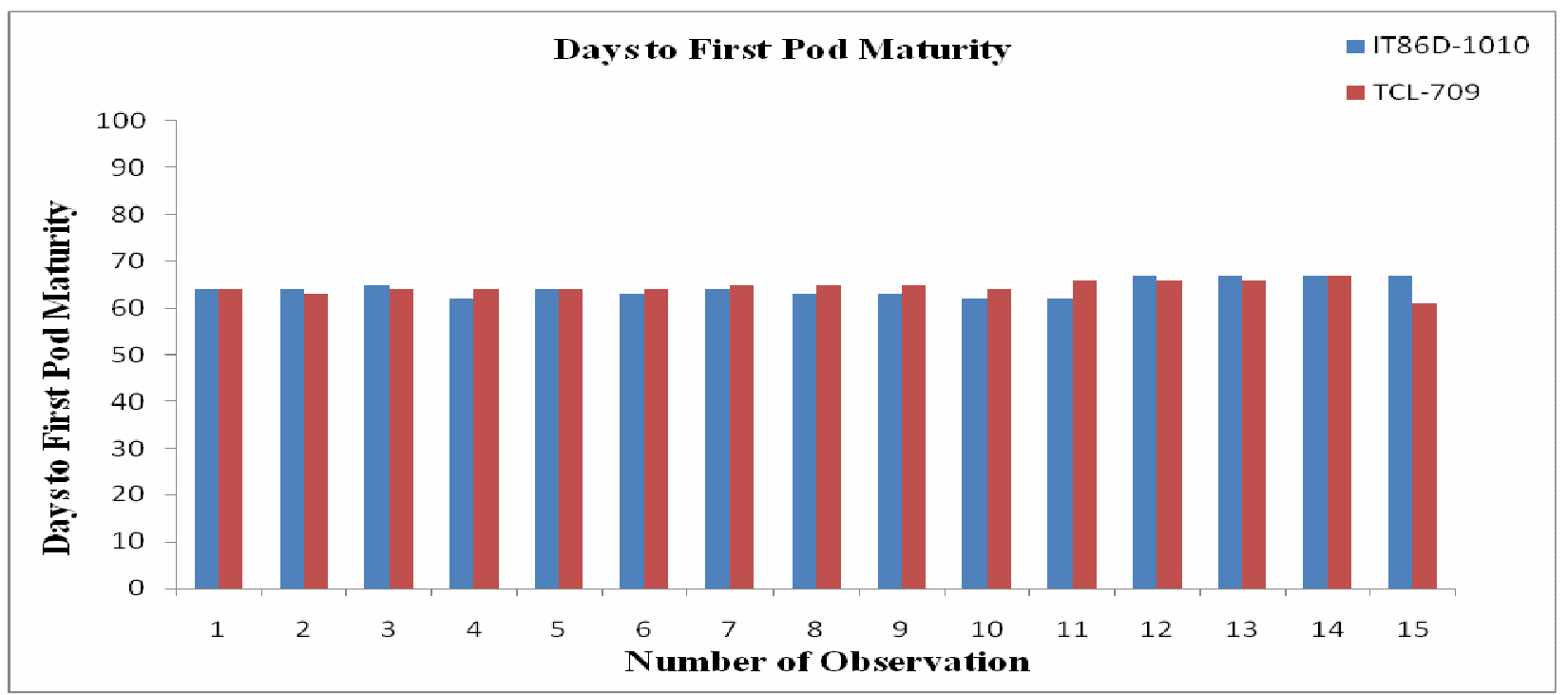

Figure 3: Days to First Pod Maturiy for IT86D-1010 and Transgenic line TCL-709 


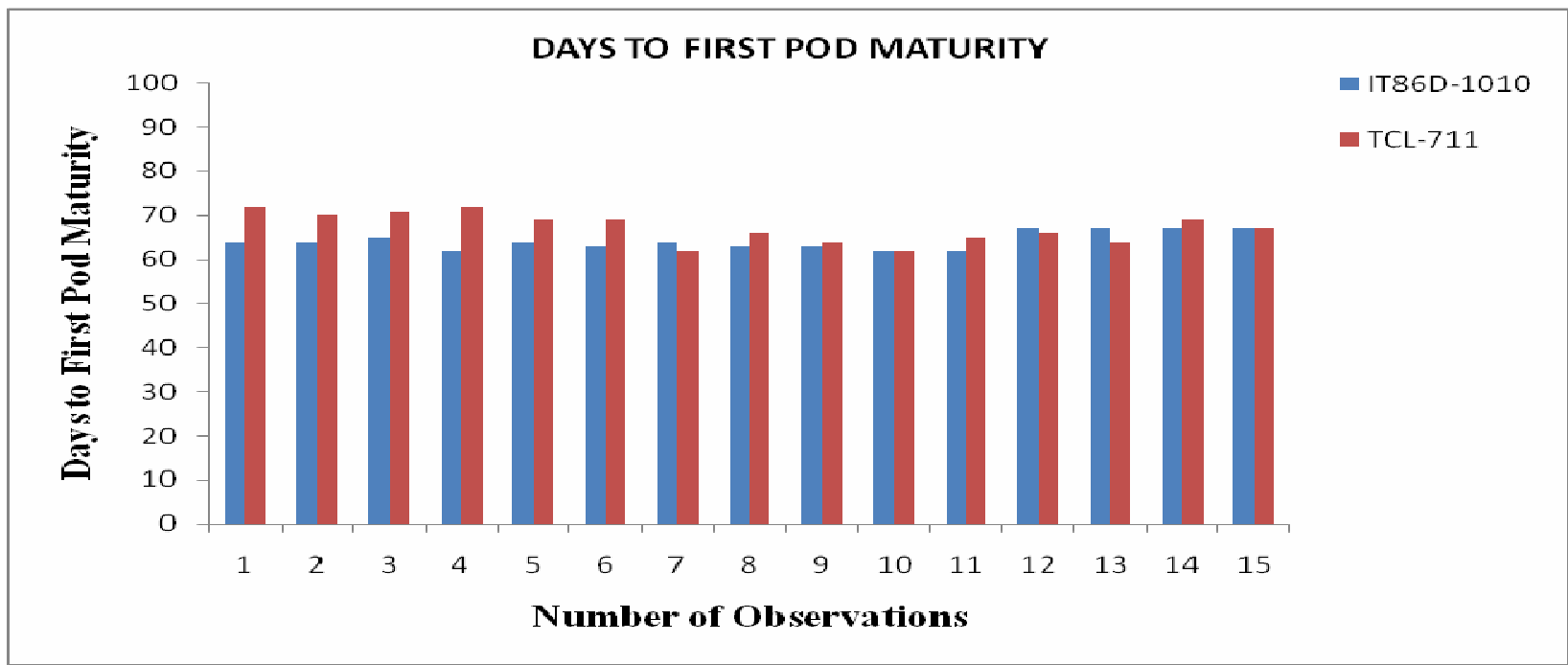

Figure 4: Days to First Pod Maturity for IT86D-1010 and Transgenic line TCL-711

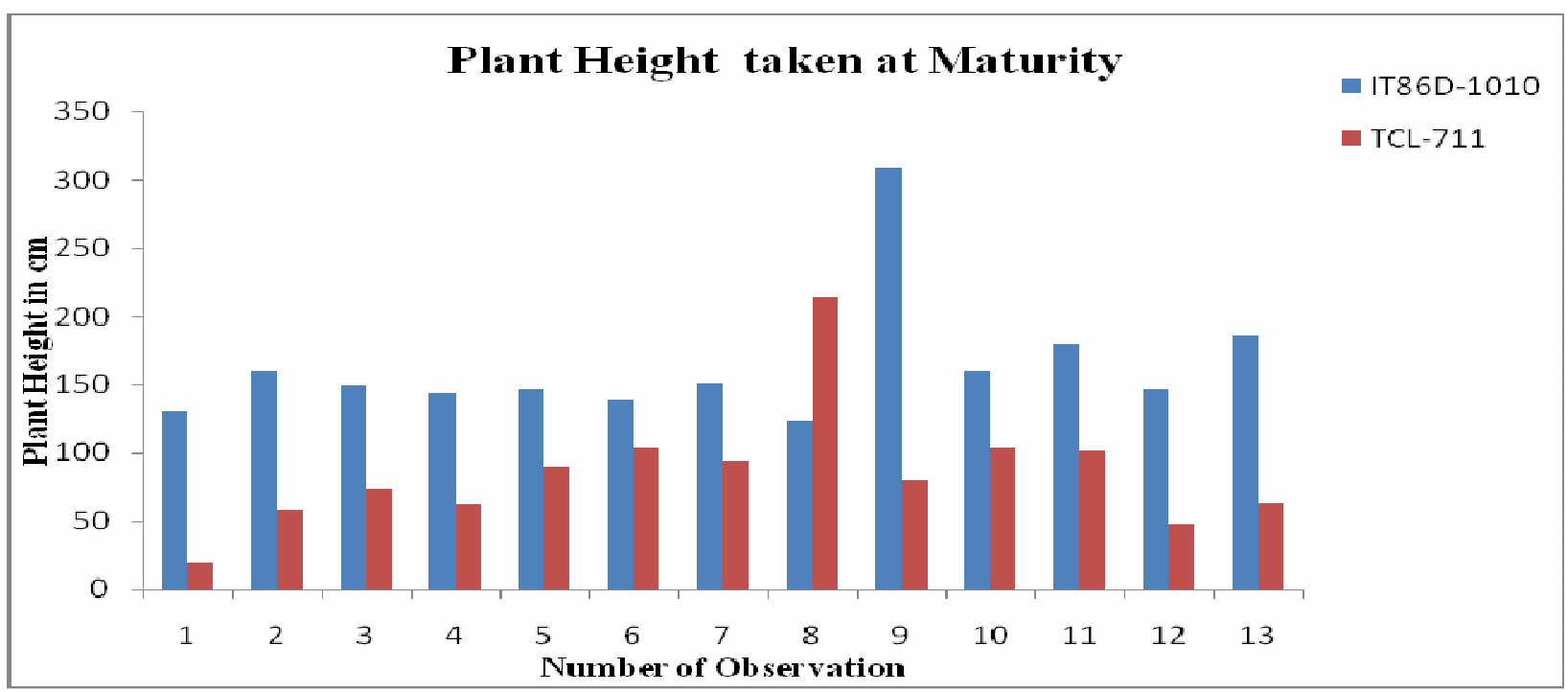

Figure 5: Plant Height data of IT86D-1010 and Transgenic line TCL-711

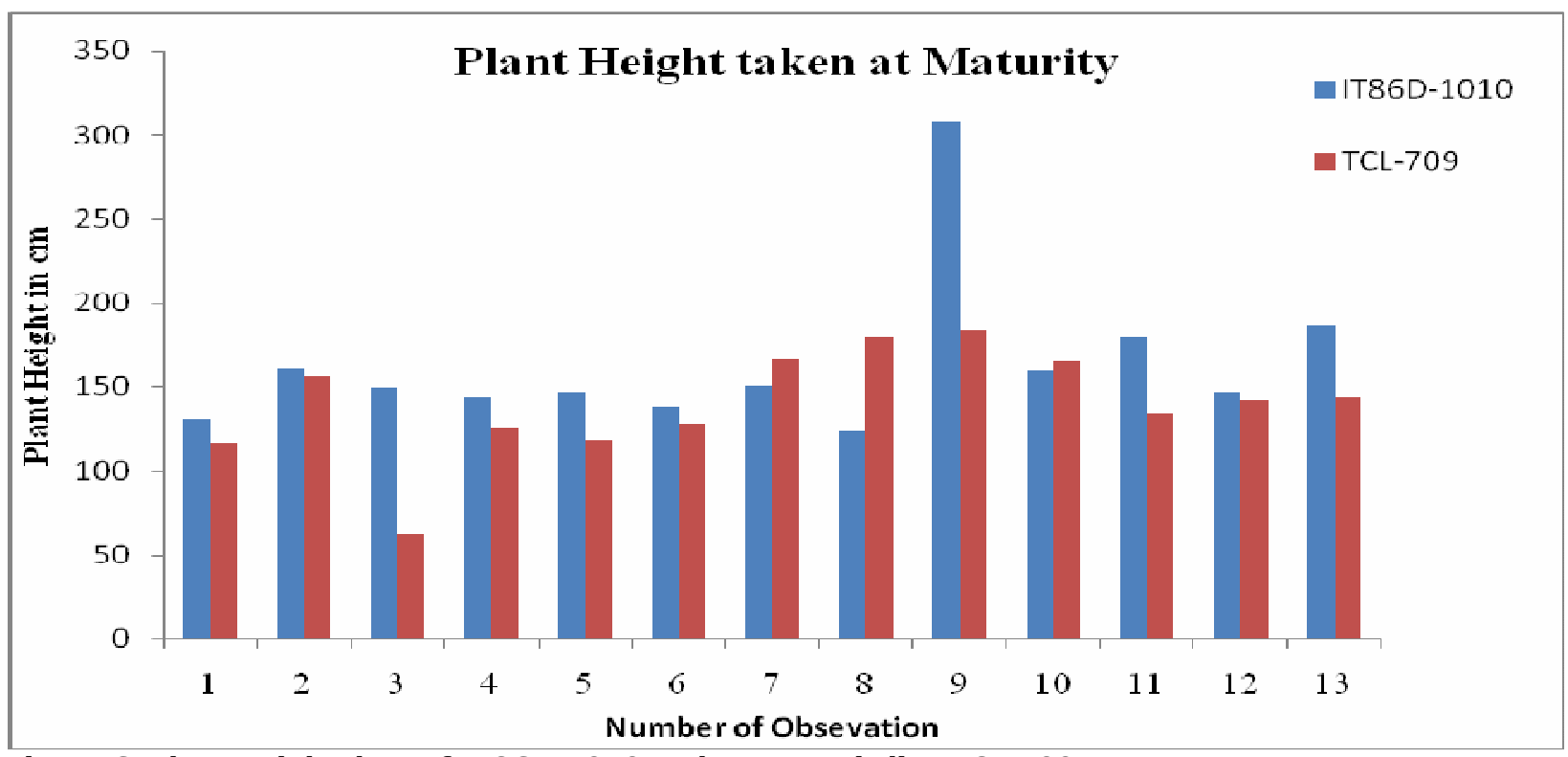

Figure 6: Plant Height data of IT86D-1010 and Transgenic line TCL-709 


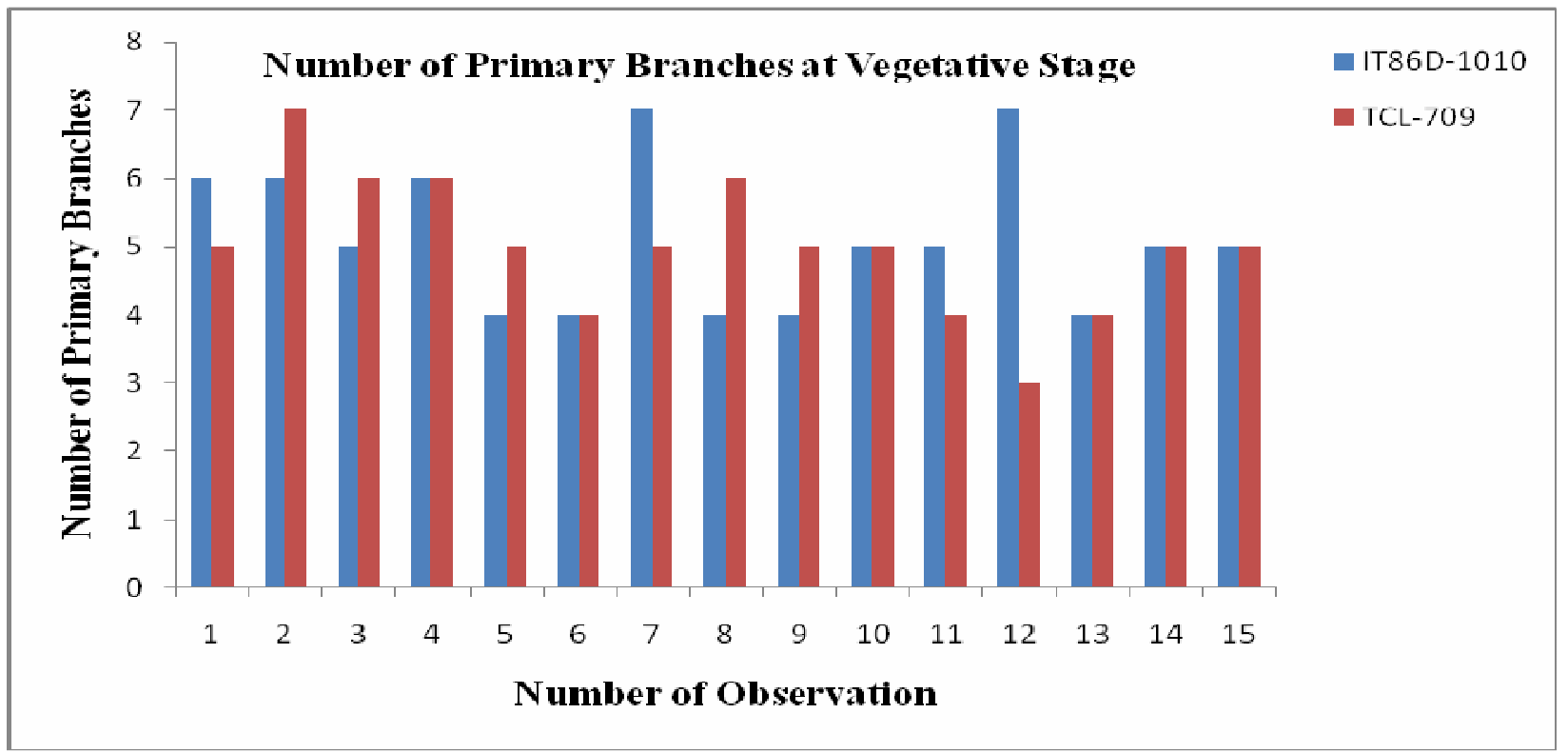

Figure 7: Number of Primary Branches at Vegetative stage for IT86D-1010 \& TCL-709

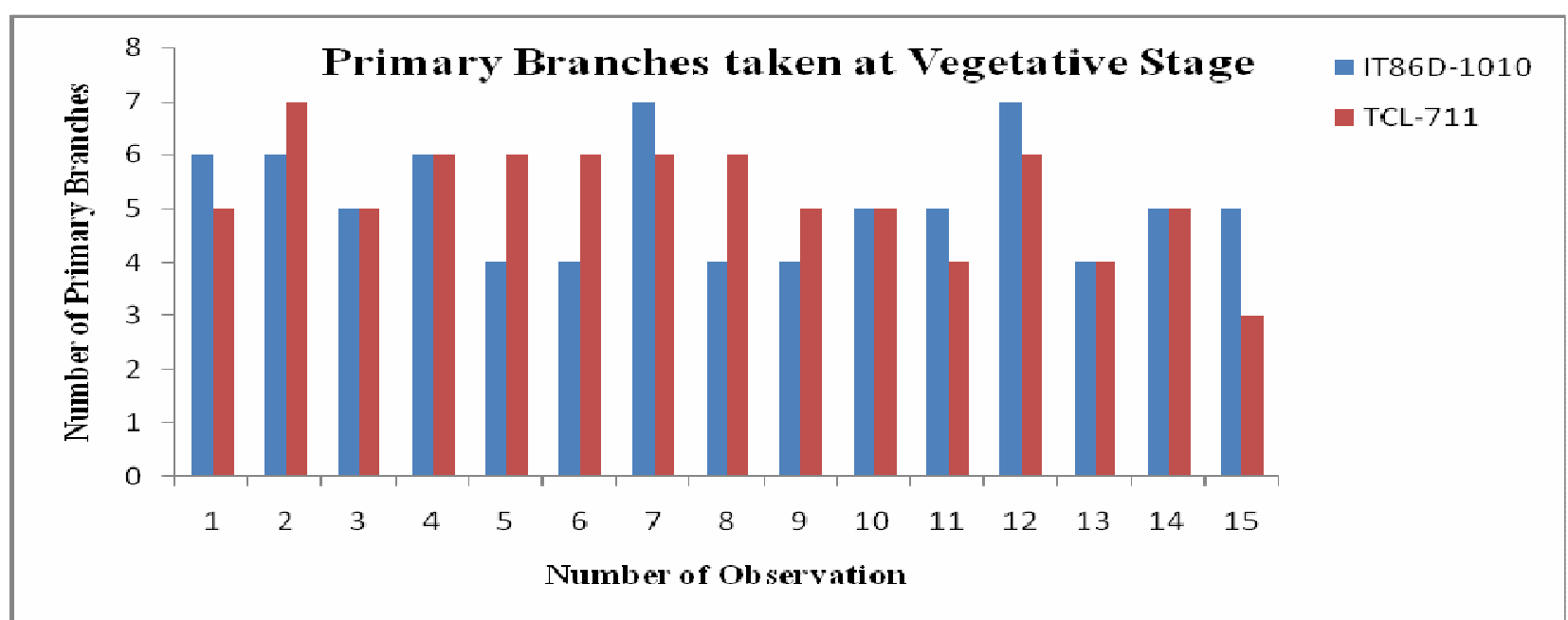

Figure 8: Number of Primary Branches at vegetative stage for IT86D-1010 \& TCL-711

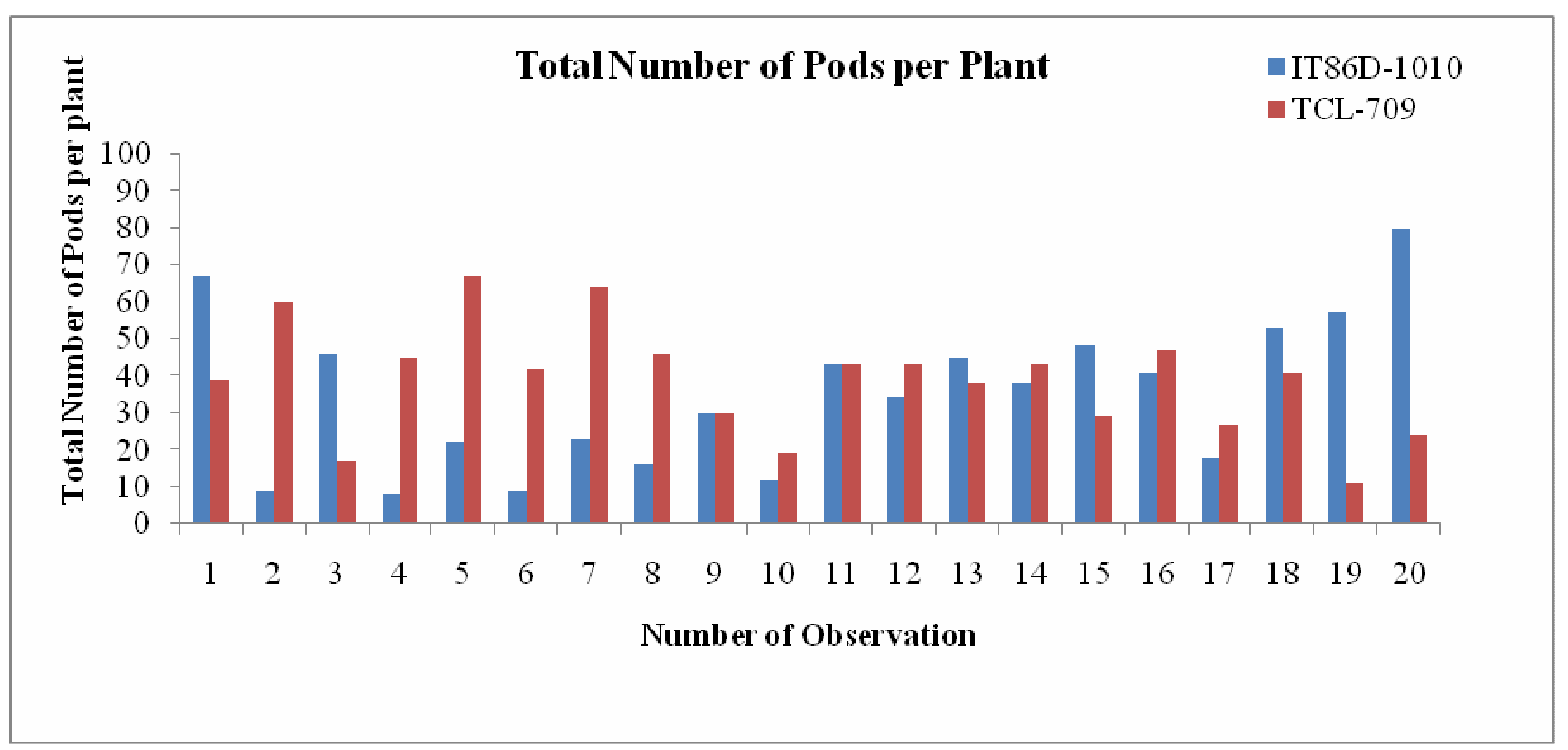

Figure 9: Total Number of Pods for IT86D-1010 and Transgenic line TCL-709 


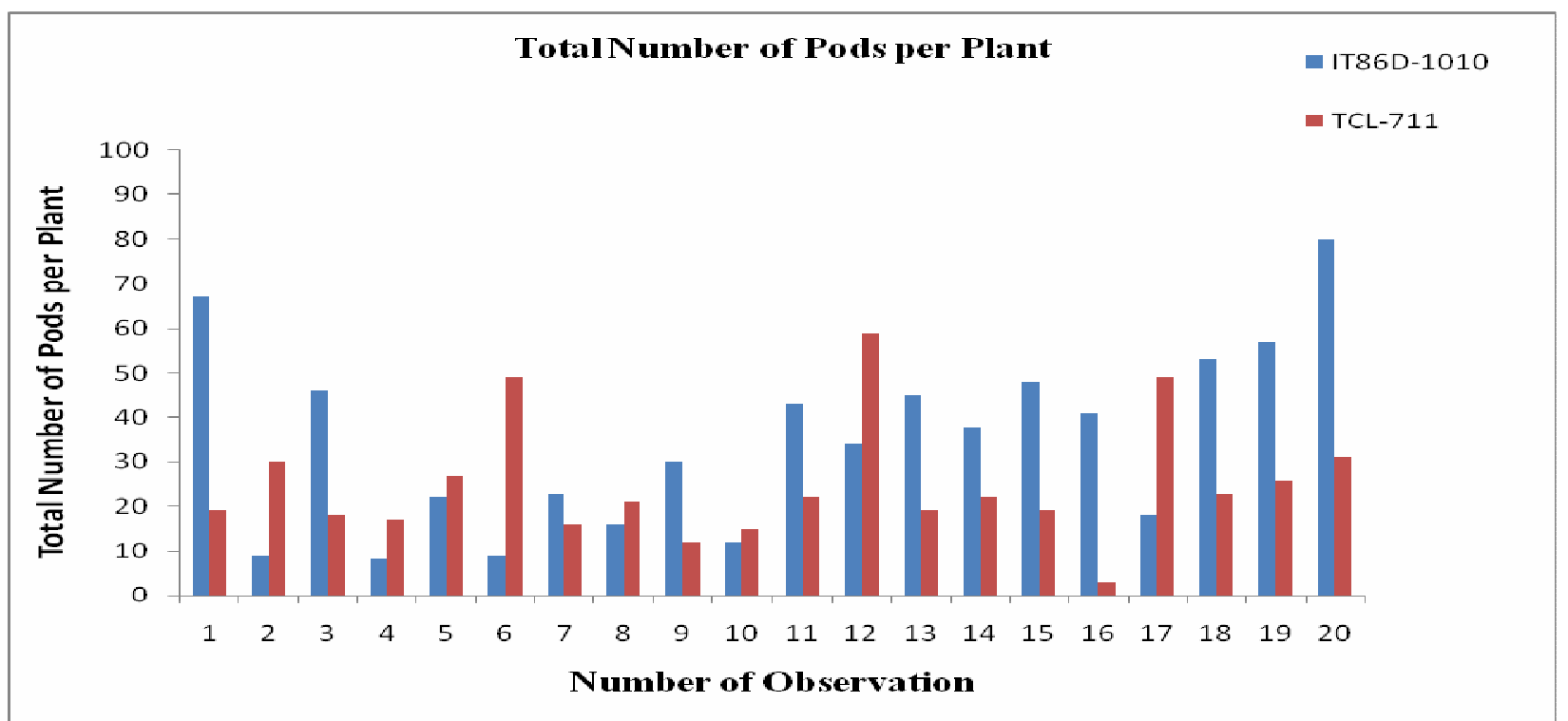

Figure 10: Total Number of Pods for IT86D-1010 and Transgenic line TCL-711

\section{DISCUSSION}

Information on the phenotype of genetically transformed cowpea plants expressing $C r y 1 A b$ gene is important for plant breeders and regulatory agencies to: identify any intentional changes to the phenotype that might be detrimental to the environmental safety and to identify unintended changes to the biology of the plant. This information includes phenotypic characteristics of the plant that might contribute to its survival or persistence or that negatively affect agricultural performance for example disease susceptibility and yield data and are usually sourced from laboratory, greenhouse and field trial studies (ANZFA, 2000a, 2000b, 2000c).

In the present study, comparison made between transgenic cowpea line TCL-709 and IT86D1010 showed no significant differences in all the parameters compared. These results are in conformity with the earlier report of Khan (2008) that Cry $1 A b$ did not affect the number of monopodial branches in cotton. The non-alteration of the characters other than for which transformation was done is highly desirable (Khan, 2008). It is thus evident that these characteristics of the plants were not affected by the transformation event and remained almost at their parental level (Khan, 2008). Since the seeds used for transformation were of an approved breeding line, it was therefore a highly positive aspect of this transformation that most of the varietal characters remained unaltered. Similarly, comparison made between cowpea transgenic line TCL-711 had significant differences for days to first flowering, days to first pod maturity and plant height while nonsignificant differences were observed for number of primary branches at vegetative stage and total number of pods per plant at maturity. Khan, (2008) reported significant changes in cotton lines transformed with $C r y 1 A b$ gene; that the transgenic plants had got other positive effects as well in addition to insect resistance, for example; the percentage ginning out-turn and number of sympodial branches per plant had increased significantly when compared with the non- transgenic parent (Khan, 2008).
Statistically significant differences have been obtained between genetically engineered plants expressing $C r y 1 A b$ and controls in many cases, but these differences were small and fell within the reported range for their conventional counterparts (ANZFA, 2000a, 2000b, 2000c). Although changes were observed in the phenology of the one of the transgenic line, generally, the phenotypic data showed no major change in the growth pattern of the crop that would support the hypothesis that the introduction of $C r y 1 A b$ transgene had any harmful effect on the gross morphological characteristics of plants, besides conferring resistance to Maruca pest (CERA, 2011).

The $C r y 1 A b$ transgene is intended to provide resistance to target insect pest- Maruca; this taken into account when phenotypic observations were made, some of the data collected were on quantitative traits such as plant height while other data are qualitative and observational such as differences in disease susceptibility. The weight of evidence from analyses of phenotypic and compositional data demonstrated that, $C r y 1 A b$ expression in approved genetically engineered crops, like maize did not alter the gross physiology of the plant, and that these plants are not more likely to become weedy or invasive than their conventional counterparts (CERA, 2011).

\section{CONCLUSION}

Assessments of impact of genetic transformation of crops are comparative by necessity, and typically involve comparisons to an untransformed parent line. The point of these comparisons is to identify potential risks the genetically transformed plant might present beyond what is already accepted for like plants in the environment. The impact of genetic transformation of cowpea with $c r y 1 A b$ gene on the morphological expression of the transgenic lines were investigated in the present study to identify any unintended changes to the biology of the plant that might negatively affect agricultural performance of these lines. 


\section{Bajopas Volume 7 Number 2 December, 2014}

In the present study, comparison made between transgenic cowpea line TCL-709 and IT86D-1010 showed non-significant differences in all the parameters compared and the un-alteration of the characters other than for which transformation was done is highly desirable. Similarly, comparison made between cowpea transgenic line TCL-711 had significant differences for days to first flowering, days to first pod maturity and plant height. Statistically significant differences have been seen between genetically transformed plants expressing $C r y 1 A b$

\section{REFERENCES}

AATF (2010). Project2; cowpea productivity improvement- guarding against Maruca infestation. Afr. Agric. Technol. Foundation. Accessed on 05/05/2010.http://www.aatfafrica.org/userfiles/Cowpea-brief.pdf

Abate, T., Alene, A.D., Bergvinson, D., Shiferaw, B., Silim, S., Orr, A. and Asfaw, A. (2012). Tropical Grain Legumes in Africa and South Asia: Knowledge and Opportunities. Nairobi, Kenya: International Crops Research Institute for the Semi-Arid Tropics.112pp.

ANZFA, (2000a). Final Risk Assessment Report Application A346 Food produced from insectprotected corn line MON 810. Australia New Zealand Food Standards Agency, http://www.foodstandards.gov.au/ srcfiles/A pplication\%20A346\%20Draft\%20I R.pdf.

ANZFA, (2000b). Final Risk Assessment Report Application A385 Food produced frominsect protected Bt-176 corn line. Australia New Zealand Food Standards Agency, Australia. http://www.foodstandards.gov.au/ srcfiles/A 385IR.pdf.

ANZFA, (2000c). Draft Final Risk Assessment Report Application A386 Food produced from insect protected, herbicide tolerant $B t-11$ corn line. http://www.foodstandards.gov.au/ srcfiles/A 386 IR.pdf.

CERA, (2011). A review of the environmental safety of the $C r y 1 A b$ protein. By Center for Environmental Risk Assessment, ILSI Research Foundation. Environ. Biosafety Res. $10 . \quad 51-71 . \quad$ Accessed 09/06/2012 on www.ebr-journal.org.

Darshana C, Seena M, Ranjana J, Raman S, Ananda PK, and Pawan PK (2007). Agrobacterium tumefaciens-mediated high frequency genetic transformation of an Indian cowpea (Vigna unguiculata L. walp.) cultivar and transmission of transgenes into progeny. Plant sci.172:92-700.

Fatokun C. 2009. Designer (Cowpea) Plants. Accessed on $10 / 12 / 2010 \quad$ from http://r4dreview.org/2009/03/designercowpea-plants/

Holdrege, C. (2008). Understanding the Unintended Effects of Genetic Manipulation. http://www.natureinstitute.org/txt/ch/nontar get.php gene and controls in many cases, but these differences were small and fell within range of conventional types. In summary, differences were observed between the original parent and one of the transgenic line used in the study but generally the morphological data showed no pattern of changes that would support the hypothesis that the introduction of Cry $1 A b$ gene had any harmful effect on the gross morphology of cowpea plants, besides conferring insect resistance to Maruca pest.

Ishiyaku M.F. (2010). Domestication of Agricultural Biotechnology in Nigeria: Challenges and Opportunities; a paper presentation to the one day sensitization workshop organized by the ARCN, IAR of the Ahmadu Bello University, Zaria. pp 6.

Khan, G.A. (2008). Inheritance of Transgene(s) in Cotton (Gossypium hirsutum I.). A thesis submitted to the University of the Punjabin complete fulfillment of the requirements for the degree of Doctor of Philosophy in Molecular Biology, University of the Punjab, Lahore. Available on http://www.scribd.com/doc/54536729/15/ Retrieved June, 2012.

Kushwaha, S., Musa, A.S., Lowenberg-DeBoer, J. and Fulton, J. (2004). Consumer Acceptance of GMO Cowpeas in Sub-Sahara Africa. American Agricultural Economics Association Annual Meeting August 3, 2004. Long Paper \#119265. Available on http://ageconsearch.umn.edu/bitstream/202 16/1/sp04ku01.pdf Accessed September, 2012.

NGICA (2002). Report of workshop on the genetic transformation of Cowpea held in Capri, Italy, October 31- November 2. pp18.

http://www.entm.purdue.edu/NGICA/reports italy proceedings.pdf

Sharma, H.C, Saxena, K.B , and Bhagwat, V.R., (1999). The legume pod borer, Maruca vitrata Bionomics and management. Information Bulletin no 55 Patancheru, Andhra Pradesh, India International Crops Research Institute for the Semi-Arid Tropics. $42 \mathrm{pp}$.

Singh, B. B., Ehlers, J.D., Sharma, B. and Filho, F.R.F. (2002). Recent progress in cowpea breeding. In; Fatokun, C.A., Tarawali, S.A., Singh,B.B., Kormawa, P.M. and Tamò, M. (eds). Challenges and opportunities for enhancing sustainable cowpea production. Proceedings of the World Cowpea Conference III held at the IITA, Nigeria, pp396. 